International Journal of Linguistics and Translation Studies

Volume 2, Issue 1, 2021

Homepage: http://ijlts.org/index.php/ijlts/index

DOI: https://doi.org/10.36892/ijlts.v2i1.105

\title{
Discovering Writing Difficulties of Malay ESL Primary School Level Students
}

\author{
Nurul Jannah Ahmad Ghulamuddin \\ Universiti Teknologi MARA Pahang, Malaysia \\ jannahghulamuddin@uitm.edu.my \\ Siti Khadijah Mohd Mohari \\ Universiti Teknologi MARA Pahang, Malaysia \\ khadijahmohari@uitm.edu.my \\ Kamisah Ariffin \\ Universiti Teknologi MARA Pahang, Malaysia \\ kamisah@uitm.edu.my
}

\section{ARTICLE HISTORY}

Received: 25/11/2020

Accepted: 09/01/2021

\section{Abstract}

Writing is perceived to be one of the most difficult skills for English language learners to master. Although studies on challenges faced by ESL students in writing are replete, most of them have focused on students at secondary and tertiary levels of education. Studies on learners at lower level have been scarce. Thus, this paper aims to fill the gap by examining the major problems faced by ESL primary school level students in writing in English. Survey and interview sessions were conducted to fit the purpose of the study. Data were collected from a class of 26 students from Year/Standard 6 of the primary school level in Malaysia and an interview session with the English teacher of that particular class. The findings indicate that the major difficulties charted are rooted in the students' poor mastery in vocabulary, inability to spell words correctly and L1 interference. Thus, in order to enhance the students' skills in writing in English, the teacher implemented some remedial measures during the teaching and learning sessions. The findings have essential pedagogical implications on understanding students' struggle to write in English at the lower level of education.

\section{INTRODUCTION}

Writing, reading, listening and speaking are the four main skills of language one should master. Name it the native language, second language or even foreign language; these four skills are looked forward to evaluate one's mastery. Among these four skills, writing is considered very challenging among the L2 learners. For ESL learners, they may be able to understand the language but most may also come across problems in communicating their ideas effectively on paper (Adas \& Bakir, 2013). This is because writing is a productive skill that is complex, challenging, and difficult process as writers are expected to produce written products that are syntactically accurate, semantically acceptable and culturally appropriate (Al-Buainain, 2009; Alsamadani, 2010; Barkaoui,2007; AlTameemy, Alrefaee, Alalwi, 2020) added that writing is a complicated task because students have to acquire macro strategies like planning, drafting and revising and micro strategies as automatic search for words and syntax. Thus, it can be concluded that it is through writing that passive knowledge on students' minds is transformed into their own language (Imsa-ad, 2020). 
In Malaysia, English is taught as the second language after the national language, Bahasa Malaysia (BM). It is one of the compulsory subjects at both primary and secondary school level. The national standard curriculum has seen few amendments since its conception with the aim of helping students to master the language at the end of their schooling years. Thus, students are integrated with the skills of speaking, listening, reading and writing in English as early as the kindergarten level. With the compulsory six years of learning English at the primary level, and another five years at the secondary level, students are expected to be competent in the four skills in the language. However, the years spent on learning the language may not make these learners competent language users ('English proficiency still a big problem', 2017; Sarudin, Zubairi, Nordi \& Omar, 2008; Spawa \& Hassan, 2013; Razak, Yassin, \& Moqbel, 2019; Ujang, 2019).

Research has shown that Malaysian students encountered problems in the application of the language skills, especially in writing (Ghabool, Mariadass \& Kashef, 2012; Yahya \& Hashim, 2013; Maarof \& Murat, 2013; Kok, Yunus \& Embi, 2017). These studies found that students struggled in their writing tasks because of their insufficient linguistic competence in English, hence, facing problems to to comprehend, conceive and compose ideas.

However, most local studies on ESL students' problems in writing have focused on students at secondary, tertiary, undergraduate and post-graduate levels (Ghabool, Mariadass \& Kashef, 2012; Maarof \& Murat, 2013; Ien, Yunus, \& Embi, 2017; Jayavalan \& Razali, 2018). Studies that focused on students at the lower level or younger age have been scarce. The writers believe that it is important to examine the root of the problem earlier so that any treatment or intervention can be effectively done during the students' tender years where the level of absorption is higher. Thus, this paper intends to fill the gap by looking at the problems faced by ESL students at the primary school level in writing and remedial measures that can be implemented in the classroom to enhance their writing skills.

\section{LITERATURE REVIEW}

Writing is an important skill for language production. However, for second language learners, it is one of the most crucial and difficult parts to the process of learning even at the tertiary level (Dixon \& Nessel 1983). This is because writing requires the writer's full concentration and attention as well as the skills in writing like grammar mastery and sentence structure (Farooq, 2012). Basically, the major issues faced by the students are related to their linguistic and cognitive skills.

There have been myriad of studies that investigated problems in ESL students' writing and the corrective measures taken to improve the students' writing skills both at the international and local contexts. Insufficient linguistic skills pose a major problem to students in their attempts to write in the second language. For example, if learners do not have a good grasp of grammar, they will not be able to produce a good piece of writing. Tyner (1987, as cited in Alfaki, 2015) put forward that 'as verbs take different forms depending on tense and subjects they are used with, they create problems for second language writing students'. Other grammar components that students often have problems with include subject verb agreements, pronoun references, and connectors. Another problem related to linguistic skills is sentence structure. Sentences can be formed in various syntactic structures. However, incapable learners often use runon, incorrect and fragmented sentences (Mekonnen, 2006).

Along the same line, Kharma (1986) claimed that students who had problems in writing good sentence structures could not produce longer sentences that required subordination and coordination. This is in agreement with Zamel's (1983) observation that cohesive devices, which are crucial in writing, were problematic for ESL students. Lacking appropriate and varied range of vocabulary is also another linguistic issue faced by the students in writing. Students tend to have problems in using appropriate words in appropriare place. For example, White (2017) observed that students usually used 'big words' to impress their teacher, and this often led to a problem of diction. In the same vein, Alfaki (2015) in his study among 
university students majoring in English in Sudan found that students' problems in writing was caused by their linguistic incapabilities. For example, the students were having difficult time to use proper tenses in their sentences. Along the same line, Zamel (1983) reported obvious incorrect usage of pronouns by the ESL students in their writing.

Second language students also face cognitive difficulties in their writing. These include problems of punctuation, capitalization, spelling, content and organization. The fact that there are no universal rules of using punctuation and capitalization makes it problematic for the students in using these mechanics properly in their writing (Croll \& Willson, 1995; Gowere et al., 1995). In addition, Gowere et al. (1995) also claimed that the inconsistency of the English spelling system, due to the influence of other languages, variant pronunciations and other historical reasons, is another complex problem that students need to deal with in their writing. A large number of students claimed that they were uninformed of the writing strategies such as the use of punctuation marks and dictionary. Nyang'au (2014) attributed this to the teacher's traditional teachings style and lack of practice among the students.

Other cognitive problems involve the content and organization of ideas. Clifford (1987) found that ESL students faced problems of exploring ideas and thoughts to communicate with others as they tended to focus more on grammar, spelling and others rather than the message that they wished to convey. In organizing their ideas, Kharma (1986) claimed that students had the problem of structuring the paragraph, topic development of a paragraph, structuring the whole discourse and a theme in a discourse. As put forward by West (1966, as cited in Tsegay, 2006), "The most common students' problem in paragraphing is either the paragraph is not limited to a single topic or the single topic is not developed or exemplified adequately". This is in line with Raimes' (1983) finding that one problem of organization in students' writing was the difficulty of differentiating a topic and supporting ideas or generalizations and specific details. On another point, Pincas (1982) also claimed that students had the problems of writing united paragraphs because they were not able to use cohesive devices appropriately.

Alfaki (2015) also observed similar cognitive issues faced by the students such as spelling, and the development and organization of the paragrapahs. The study also reported that the students were not able to generate relevant ideas on the theme of the essay. Similarly, Kharma (1986) observed that the students were unable to come up with an appropriate topic sentence and further logical supporting sentences. To add, Ashraf, Fareed \& Bilal (2016) in their study on writing problems among ESL learners in Pakistan also attributed the problems to linguistic and cognitive-related issues such as grammar and syntax, and inappropriate ideas development. They also reported interference from the students' native tongue as direct translation of expressions in Urdu was preeminent in their English essay.

These empirical studies also suggested possible solutions that can asssist the students in their writing which included encouraging reading among students and practising free writing and note taking in order to polish the skills to generate ideas. Alfaki (2015) and Ashraf et al. (2016), for example, encouraged teachers and parents to foster reading culture among L2 students. Students would learn new vocabulary through incidental or intentional vocabulary learning which would ensure better retention in their minds. In addition, teachers were also encouraged to conduct regular writing sessions with the students. However, teachers must refrain themselves from asking the students to write on recurrent topics. This is because students would have a tendency to to produce similar pieces of writing when asked to write on a topic repetitively (Ahmed, 2010). The issue of motivation to write should also be examined further as highlighted by Nik, Sani, et al. (2010). They claimed that many L2 students were not interested to better their writing skills at all apart from the sake of completing tasks in their examinations. By providing positive and constructive feedback to students, the researchers believed that this would intensify their motivation level and inspire them write more. They also suggested quizzes and competitions to be conducted occasionally as one of the ways to motivate them. In addition, Nunan (2003) also recommended the use of dictionary to reduce the L1 inteference when the students write their essays. Concurrently, it 
could benefit the students to develop a rich vocabulary. Other than that, EFL teacher should be exposed with other exciting, more effective methods to improve their students' writing skills. Ample of online materials are readily accessible and could be utilised for the purpose. Nevertheless, they must be selected with caution as they need to accommodate to the precise needs of the students.

In short, most studies conducted in both local and international contexts have addressed the problems in writing in English among ESL learners at higher level of studies such as secondary, tertiary and even post-graduate levels. The present study would contribute to the body of knowledge as it examined the issue at the lower level, i.e., primary school level so that the problems can be identified and rectified at earlier stage of learning.

\section{The Study}

The main objectives of this study were to identify the problems faced by primary school level ESL learners in writing and to find out the supports given by the teacher to enhance their skill in writing. Thus, the research questions can be expressed as follows:

i. What are the major difficulties faced by ESL primary level students in writing in English?

ii. What are the supports given by the teacher to enhance the students' skills in writing in English?

\section{METHODOLOGY}

The study involved ESL primary school students (aged around twelve years old) and a teacher teaching English to the selected group of students. The students were selected based on convenience sampling because the researchers had to agree to the terms and conditions set by the school regarding using students as research sampling. Thus, with the consent of the Head of the English Panel in the school, who was also the teacher teaching English to the group, a class of twenty-six students from Year/Standard 6 of the primary school level was selected. In Malaysia, primary education begins at age seven and lasts for six years, and is referred to as Year/Standard 1 to 6 . The students were all Malay by race with Bahasa Malaysia (BM henceforth) as their mother tongue. The teacher was a certified ESL (English as a Second Language) teacher with 25 years of teaching experience.

According to the teacher, this was a mixed-ability class with average performance in English where out of 26 students, 18 obtained grade B, 5 scored grade C and 3 managed to get grade D in the English subject in the Mid-Year Examination. It is important to note that, although they had received the same amount of English instruction since pre-schooling until the present, their proficiency in the language varied. In addition, they hardly used English in their daily routine. For most of them, English was only heard and used during class sessions.

This study employed both quantitative and qualitative research approaches. Quantitatively, the data collection involved a survey using questionnaire that was adapted from Farooq's (2012) six constructs on writing difficulties in the English language. The questionnaire contained 18 statements related to vocabulary, spelling, grammar, punctuation, rhetorical problems and L1 interference on five-point Lickert scale. The statements were written both in English and Bahasa Melayu (BM) to ease the students' understanding. Table 1 shows the constructs of the difficulties and the statements for each.

Table 1: Constructs on Writing Difficulties (Farooq, 2012)

\begin{tabular}{ll}
\hline Constructs & Statements \\
\hline Vocabulary & a. $\quad$ Writing is difficult for me because I have lack of vocabulary. \\
& b. $\quad$ I use some simple words to replace the difficult ones. \\
\hline
\end{tabular}




\begin{tabular}{|c|c|}
\hline & c. I use different words to express the similar meanings. \\
\hline Spelling & $\begin{array}{l}\text { a. I face problems to write spellings of the word that is new to } \\
\text { me. } \\
\text { b. I take time to recall what exact spelling is. } \\
\text { c. I get poor grades because of poor spellings. }\end{array}$ \\
\hline Grammar & $\begin{array}{l}\text { a. The frequent problem which I face while writing is the correct } \\
\text { use of tenses. } \\
\text { b. I usually find it difficult to understand sentence structures in } \\
\text { English. } \\
\text { c. Grammatical mistakes affect my expression in writing. }\end{array}$ \\
\hline Punctuation & $\begin{array}{l}\text { a. I am often confused in the use of punctuation marks. } \\
\text { b. My sentences don't convey complete sense as I am not good at } \\
\text { marking commas in sentences. } \\
\text { c. The reason of poor performance in writing is the incorrect use } \\
\text { of punctuation marks. }\end{array}$ \\
\hline $\begin{array}{l}\text { Rethorical } \\
\text { problems }\end{array}$ & $\begin{array}{l}\text { a. My written expression is not good in describing the past } \\
\text { events. } \\
\text { b. I feel confused while referring to the things which I have } \\
\text { already mentioned in my writing. } \\
\text { c. I face problems in connecting one paragraph with the other. }\end{array}$ \\
\hline L1 interference & $\begin{array}{l}\text { a. I write English essays in the way I do in BM. } \\
\text { b. I think of a sentence in Malay first and then translate it into } \\
\text { English. } \\
\text { c. I sometimes use BM words when I can't find the exact English } \\
\text { expressions. }\end{array}$ \\
\hline
\end{tabular}

The questionnaires were distributed to the students right after an English writing class so that the students would be able to recall their experience in completing the writing task. They were asked to answer the questionnaire individually and not to discuss their answers with their friends. This was to ensure the responses were honest and based on their own experience.

The qualitative approach involved an interview with the teacher. Information was gauged regarding the teacher's observation on the students' difficulties in writing and the kind of support provided to enhance the students' skills in writing.

\section{DATA ANAL YSIS}

Data from the questionnaire were quantitatively analysed and computed based on the means of the items in each construct to identify which aspect had the most influence in terms of difficulties faced in writing among the students. The qualitative data from the interview were analysed using the conventional content analysis approach based on Farooq's (2012) constructs.

\section{FINDINGS AND DISCUSSION}

\section{Difficulties in Writing in English}

The analysis shows that the students faced difficulties in their ESL writing in all the constructs. Table 2 shows the overall analysis on the difficulties based on the six constructs examined.

Table 2: Difficulties in Writing based on Constructs 


\begin{tabular}{lc}
\hline Construct & Mean \\
\hline Vocabulary & 1.77 \\
\hline Spelling & 1.27 \\
\hline Grammar & 0.89 \\
\hline Punctuation & 0.48 \\
\hline Rhetorical Problems & 0.89 \\
\hline L1 Interference & 1.12 \\
\hline
\end{tabular}

The analysis indicates that the biggest hurdle to writing in English is vocabulary $(\mathrm{M}=1.77)$. This supports earlier findings that vocabulary is always an issue in students' writing (Ashraf, Fareed \& Bilal, 2016; Yahya \& Hashim, 2013). The second major difficulty faced by the students in writing in English was spelling $(\mathrm{M}=1.27)$. This problem is very much related to the vocabulary problem. When students are not familiar with new words or lack knowledge of the appropriate words to be used in their writing, they tend to face problems in the spelling of words. This, in turn, may lead to other problems in writing such as making the correct meaning. As attested by Silva and Yarborough (1990), inability to spell may lead to word choices that can falsify the meaning. The third major problem reported is L1 interference $(\mathrm{M}=1.12)$. This is followed by grammar $(\mathrm{M}=0.89)$, rhetorical problems $(\mathrm{M}=0.89)$ and punctuation (0.48).

Table 3 shows the detailed analysis of each of the constructs examined. The score on each of the questionnaire statements were able to indicate the factors contributing to the students' problems in writing in English.

Table 3: Difficulties in Writing based on Constructs

\section{Vocabulary}

\begin{tabular}{|c|c|c|}
\hline No & Statement & Mean \\
\hline 1 & Writing is difficult for me because I have lack of vocabulary. & 1.15 \\
\hline 2 & I use some simple words to replace the difficult ones. & 2.65 \\
\hline 3 & I use different words to express the similar meanings. & 1.5 \\
\hline \multicolumn{3}{|c|}{ Spelling } \\
\hline 4 & I face problem to write spellings of the word that is new to me. & 1.38 \\
\hline 5 & I take time to recall what exact spelling is. & 1.73 \\
\hline 6 & I get poor grades because of poor spellings. & 0.69 \\
\hline \multicolumn{3}{|c|}{ Grammar } \\
\hline 7 & $\begin{array}{l}\text { The frequent problem which I face while writing is the correct use of } \\
\text { tenses. }\end{array}$ & 0.58 \\
\hline 8 & I usually find difficult to understand sentence structure in English. & 0.81 \\
\hline 9 & Grammatical mistakes affect my expression in writing. & 1.27 \\
\hline \multicolumn{3}{|c|}{ Punctuation } \\
\hline 10 & I am often confused in the use of punctuation marks. & 0.35 \\
\hline 11 & $\begin{array}{l}\text { My sentences don't convey complete sense as I am not good at marking } \\
\text { commas in sentences. }\end{array}$ & 0.16 \\
\hline 12 & $\begin{array}{l}\text { The reason of poor performance in writing is the incorrect use of } \\
\text { punctuation marks. }\end{array}$ & 0.92 \\
\hline \multicolumn{3}{|c|}{ Rhetorical Problems } \\
\hline 13 & My written expression is not good in describing the past events. & 1.62 \\
\hline 14 & $\begin{array}{l}\text { I feel confused while referring to the things which I have already } \\
\text { mentioned in my writing. }\end{array}$ & 0.58 \\
\hline 15 & I face problems in connecting one paragraph with the other. & 0.46 \\
\hline
\end{tabular}




\begin{tabular}{llr}
$\mathbf{1 6}$ & I write English essays in the way I do in BM. & 0.58 \\
\hline $\mathbf{1 7}$ & I think of a sentence in BM first and then translate it into English. & 2.31 \\
\hline $\mathbf{1 8}$ & $\begin{array}{l}\text { I sometimes use BM words when I can't find the exact English } \\
\text { expressions. }\end{array}$ & 0.46
\end{tabular}

As mentioned earlier, vocabulary poses the biggest problem to the students when it comes to writing in English. The students admitted that writing was difficult for them as they lacked the vocabulary needed to write. This is supported by the teacher during the interview. She claimed that students had ideas to write but the lack of vocabulary hindered them from producing good writing. The analysis, as shown in Table 2, indicates that students used certain strategies to help them overcome the vocabulary problem in writing. They claimed that they 'use simple words to replace the difficult ones' $(\mathrm{M}=2.65)$, and 'use different words to express the similar meanings' $(M=1.5)$. However, according to the teacher, the 'simple words' and 'different words' that the students used in their writing were actually words in their L1, i.e., BM. When the students were not able to think of words that they needed in English, they tended to revert to L1 and used the words in their writing. Thus, sentences that contained BM words like 'My parents menghargai (appreciate) my efforts', 'Every evening, I play guli (marbles) with my friends in front of my house' and 'The old man is botak (bald)' were quite common in their writing.

As spelling is related to vocabulary, it is not a surprise to find that this construct ranks the second highest in the difficulties faced by the students in their writing. According to Mpiti (2012) spelling is as a process that encompasses phonological, morphological and syntactic skills, semantic knowledge, and the ability to formulate words based on visual memory along with applying the orthographic rules. This can be difficult especially when the words are unfamiliar to the students. As shown by the analysis, the students faced problem to write spelling of the word that was new to them $(M=1.38)$. Furthermore, the lack of knowledge on the English spelling rules and their exceptions can confuse ESL learners. The teacher claimed that students often did not remember the spelling rules as the pronunciation of the word and its spelling differ. Thus, writing lessons usually turned into spelling lessons as the students need to be retaught the rules of the spelling as they took time to remember the correct spelling of the words. This is in line with the analysis that shows students took time to recall what was the exact spelling of the word $(M=1.73)$. This concurs with Alfaki's (2015) finding that spelling is one of the mechanical mistakes that is common among the students apart of punctuation and capitalization. However, in this current study, punctuation ranks the lowest in the difficulties faced by the students in their writing. Although they knew that their incorrect use of punctuation could lead to poor performance in writing, only a minority felt that they did not master the use of punctuation $(\mathrm{M}=0.35)$ and were not able to make sense in their writing due to poor mastery of punctuation usage $(\mathrm{M}=0.16)$.

The analysis indicates that L1 interference is the third difficulty faced by the students in their writing tasks. The analysis reveals that L1 plays an important role in shaping the students' writing. The majority of the students claimed that when writing in English, they would think of a sentence in BM first, then translate it into English $(\mathrm{M}=2.31)$. The interview with the teacher concurs with this claim as the students usually would think of what to write in BM, and later translate it into English. This occurred at both sentence and word level. Thus, it would be very common to find English sentences written in the Malay language structure, and Malay words or phrases in the English sentences (if they did not know certain words or phrases) in their writing. In addition, the teacher also claimed that the L1 interference was also evident in the students' spelling of the English words. In the BM, the spelling of a word follows the way it is pronounced. Thus, these students tended to use the same method of spelling with the English words. They would spell the English words, especially the unfamiliar ones, based on the pronunciation. Such finding supports earlier studies that L1 interference is one of the problems faced by the learners which consequently 
contribute to their errors in writing (Abushibab, 2014; Ghabool et al. (2012); Nalliveettil \& Mahasneh, 2017; Watcharapunyawong \& Usaha, 2013).

Another difficulty faced by the students was grammar. They felt that lacking the mastery of English grammar affected their ability to express their ideas in their writing $(\mathrm{M}=1.27)$. This is not surprising as other studies have also shown that grammar poses a major problem to ESL students even at higher levels (Goldsmith \& Sujaritjan, 2020; Nair \& Hui, 2018; Zheng \& Park, 2013). According to the teacher, the common grammatical problems faced by these students included sentence structure, subject-verb agreement, tenses and parts of speech. One of the main factors for the grammatical problem was the L1 interference. As mentioned earlier, the students would apply the L1 structure when writing in English, hence, producing sentences with incorrect structure. In addition, students often had problems in using the correct subject-verb agreement and verb tenses in their writing because there are no such concepts in their L1. Similarly, the students would have problems in using the correct parts of speech, such as articles and gender pronouns, as such concepts are also not available in their L1. As attested by Ashraf and Fareed (2016), ESL learners relied too much on the theory of sentence structure from their native language. Thus, they tended to directly translating any words or sentence from their L1 to English which most of the times, could affect the sentence structure as well as the grammar.

The analysis also shows that the students faced some rhetorical problems in their writing. The finding reports that they had problems in describing events in the past $(\mathrm{M}=1.62)$ and connecting ideas $(\mathrm{M}=0.58)$ and paragraphs $(\mathrm{M}=0.46)$. Having looked at these rhetorical problems, it can be inferred that the problems were actually rooted in the previous problems presented. The students would not be able to express and organise their ideas in writing when they lacked vocabulary and had insufficient mastery of English spelling, structure and grammar. Even studies at higher level also highlighted similar problems faced by ESL students. These studies reported that the students faced difficulties in grammatical, paragraph organization, coherence, cohesion, diction and vocabulary misspelling (Ariyanti \& Fitriana, 2017; Pratiwi, 2016).

\section{Teacher's Support to Enhance Students' Skills in Writing}

The analysis has shown that the major aspect that hinders good writing in English among the students was the lack of vocabulary. When students do not have sufficient vocabulary in English, it impedes their creativity and they may end up using the same words in their writing (Adas \& Bakir, 2013). In addition, good writing also requires good grammar. Anwar and Ahmed (2016) put forward that if students are unable to master the basic of these two elements, writing will be difficult for them.

The teacher in this study believed that the aspects of vocabulary and grammar must be tackled first before other aspects such as rhetorical problems and L1 interference. This is because once these two major issues are dealt with, problems in spelling and punctuation can be consequently resolved. Other issues that relate to rhetorical problems and L1 interference can be taught incidentally in the grammar lessons.

To enhance the students' vocabulary, the teacher came out with two different techniques. The first one is on vocabulary building. For this technique the teacher would introduce several words daily and students had to compile the new words in their vocabulary book, together with the meaning and sample sentences. Students needed to memorize the words, meaning and spelling. At the end of each week, the teacher would conduct activities based on the words given during the week. These included spelling bee contests, spelling tests and word games. Such activities were able to empower and expand the students' vocabulary. This corresponds with Cadena and Leguizamon's (2010) findings that writing skills can be enhanced by practising spelling among language learners. The other technique was related to the writing activity itself. Here, the teacher would introduce vocabulary related to the topic prior to the writing task. According to the teacher, when the students were 
introduced with the appropriate vocabulary to the topic, they were able to use the words in their writing without having to use words in BM. This indicates that students would perform better if they were provided with the words that they need for their writing. Studies have also shown that once the students are enhanced and pre-taught with vocabulary, they can develop better writing (Ashraf, Fareed \& Bilal, 2016; Cole \& Feng, 2015).

While the syllabus states that the English language should be taught integratively, communicatively and incidentally, the teacher strongly believed that grammar rules should be taught explicitly. This is because not all students are able to deduce the rules when grammar is taught implicitly. Thus, grammar topics like subject-verb agreement and tenses were taught explicitly to ensure the students' understanding. This was followed by reinforcement exercises that included drilling, grammar games and competitions. Reinforcement on grammar is considered as a product approach that can affect the finish written products (Anwar \& Ahmed, 2016) and the mastery of grammar can affect one's competence in writing (Elfatah \& Ahmed, 2016). The teacher's effort is in congruent to other several research that found out grammar exercises help students to improve their writing (Jayavalan \& Razali, 2018; Myhill, 2005). All these are indirectly proportional to the particular support by the teacher for the students to polish on their grammar skills.

As for the rhetorical problems, the teacher supported the students by giving them stepby-step guidance to writing. This included guiding them to prepare an outline prior to writing the essay. Once the students were able to come out with a framework of their essay, she would then guide them into writing the paragraphs. This included the content that dealt with main ideas and supporting details, and the mechanics of writing such as the use of linkers and discourse markers. The teacher also believed that the students also need to know their performance in writing. This is because feedback is essential to develop and improve students' academic writing skills (Hyland \& Hyland, 2019; Nicol \& Macfarlane, 2006). Thus, she would provide feedback to the students' work either orally or in written. This could assist the students in improving their writing skills.

\section{CONCLUSION}

Writing is considered as the hardest language skill to be mastered, especially when it comes to a language which is not the mother tongue of the people (Dixon \& Nessel, 1983). This study has examined the difficulties faced by ESL students at the primary school level in writing. The findings indicate that the major difficulties in writing in English for these students were lack of vocabulary and grammar. Other issues, such as L1 interference, punctuation, spelling and rhetorical problems, also posed difficulties to student writing. The teacher had supported the students by developing and enhancing their writing skills in terms of vocabulary, grammar and writing guidance.

This study has shown that difficulties in writing in English occur at early level of learning. However, empirical research has focused on the issue mostly at higher levels of learning. Perhaps, this study is a turning point where researchers should shift their focus at the early level of learning so that this issue can be dealt with earlier rather than at the level where issues pertaining issues like grammar and L1 interference tend to have been fossilized.

\section{REFERENCES}

Abushihab, I. (2014). An Analysis of Grammatical Errors in Writing Made by Turkish Learners of English as a Foreign Language. International Journal of Linguistics, 6(4), 213-223.

Adas, D., \& Bakir, A. (2013). Writing Difficulties and New Solutions: Blended Learning as an Approach to Improve Writing Abilities. International Journal of Humanities and Social Science, 3(9), 254-266. 
Ahmed, A. H. (2010). Students' problems with cohesion and coherence in EFL essay writing in Egypt: Different perspectives. Literacy Information and Computer Education Journal (LICEJ), 1(4), 211-221.

Al-Buainain, H. (2009). Students' Writing Errors in EFL: A Case Study. Journal of Faculty of Education, 19(1), 311-351.

Alfaki, I. M. (2015). University Students' English Writing Problems: Diagnosis and Remedy. International Journal of English Language Teaching, 40-52.

Al-Gharabally, M. (2015). The Writing Difficulties Faced by L2 Learners and how to Minimize Them. International Journal of English Language and Linguistics Research, 3(5), 42-49.

Alsamadani, H. A. (2010). The relationship between Saudi EFL students' writing competence, L1 writing proficiency, and self-regulation. European Journal of Social Sciences, 16(1), 53-63.

AlTameemy, F. A., Alrefaee, Y. \& Alalwi, F. S. (2020). Using Blackboard as a Tool of E-Assessment in Testing Writing Skill in Saudi Arabia. Asian ESP Journal, 16 (62). 183-202.

Anwar, M. N., \& Ahmed, N. (2016). Students' Difficulties in Learning Writing Skills in Second Language. Science International Lahore, 28(4), 735-739.

Ariyanti, A., \& Fitriana, R (2017). EFL students' difficulties and needs in essay writing. Advances in Social Science, Education and Humanities (ASSEHR), 158: 111-121.

Ashraf, A., Fareed , M., \& Bilal, M. (2016). ESL Learners' Writing Skills: Problems, Factors and Suggestions. Journal of Education \& Social Sciences, 4(2), 81-92.

Barkaoui, K. (2007). Teaching writing to second language learners: Insights from theory and research. TESL reporter, 40(1), 35-48.

Cadena, M., \& Leguizamon, Y. (2010). Improving Spelling Skills in Kindergarten through Jclic Activities. [Unpublished Thesis]. Universidad de la Sabana.

Cole, J., \& Feng, J. (2015). Effective Strategies for Improving Writing Skills of Elementary English Language Learners. In Chinese American Educational Research and Development Association Annual Conference, (pp. 2-24). Chicago.

Croll, J. A, \& Willson, E. E. (1995). Acts of teaching. How to teach writing. A text, a reader, a narrative. Teacher Ideas Press.

Dixon, C., Nessel D. (1983). Language Experience Approach to Reading and Writing : Language Experience Reading for Second Language Learners. The Alemany Press.

Elfatah, M. A., \& Ahmed, A. S. (2016). Using Facebook to Develop Grammar Discussion and Writing Skills in English as a Foreign Language for University Students. Sino-US English Teaching, 13(1), 932-952.

English proficiency still a big problem for many M'sian grads. (2017, January 21). The Star. Retrieved from https://www.thestar.com.my/news/nation/2017/01/21/englishproficiency-still-a-big-problem-for-many-msian-grads/

Farooq, M. S. (2012). Opinion of Second Language Learners about Writing Difficulties in English Language . South Asian Studies, 27(1),183-194. 
Genhard, J. G. (1996). Teaching English as a foreign language: A teacher self-development and methodology. Ann arbor: the university of Michigan press.

Ghabool, N., Mariadass, M. E. \& Kashef, S. H. (2012). Investigating Malaysian ESL Students' Writing Problems on Conventions, Punctuation, and Language Use at Secondary School Level. Journal of Studies in Education, 2(3), 130-143.

Goldsmith, A. \& Sujaritjan, P. (2020). An Analysis of Grammatical Errors Made by 3rd-Year Thai Business English Undergraduates When Spontaneously Writing Narrative and Descriptive Paragraphs. International Journal of Research GRANTHAALAYAH, 8(8), 75-95.

Gowere, R., Philips, D. and Walters, S. (1995). Teaching Practice Handbook. Oxford, Heinemann.

Hyland, K. \& Hyland, F. (eds.) (2019). Feedback in Second Language Writing: Contexts and Issues. Cambridge University Press.

Ien, L. K., Yunus, M. M., \& Embi, M. A. (2017). Build me up: Overcoming writing problems among pupils in a rural primary school in Belaga, Sarawak, Malaysia. Jurnal Pendidikan Humaniora, 5(1), 1-7.

Imsa-ard, P. (2020). Being an Effective Writing Teacher: Understanding Writing Theories behind the Product, Process, and Genre Approaches. International Journal of Linguistics and Translation Studies, 1(2), 35-47.

Jayavalan, K., \& Razali, A. B. (2018). Effectiveness of Online Grammar Checker to Improve Secondary Students' English Narrative Essay Writing. International Research Journal of Education and Sciences (IRJES), 2(1), 1-6.

Kharma N. (1986, July). Composition Problems; Diagnosis and Remedy. In English Teaching Forum. 24(3), 21-28.

Maarof, N., \& Murat, M. (2013). Writing Strategies Used by ESL Upper Secondary School Students. International Education Studies, 6(4), 47-55.

Mekonnen, T. (2006). The Writing Problems of Preparatory II Students with Reference to Injibara Preparatory School. [Unpublished MA Thesis]. Addis Ababa University.

Mpiti, T. (2012). The nature of spelling errors of grade three isiXhosa background students in English first additional language. [Unpublished master's thesis]. University of Fort Hare, South Africa.

Myhill, D. (2005). Ways of Knowing: Writing with Grammar in Mind. English Teaching: Practice and Critique, 4(3), 77-96.

Nair, S. M, \& Hui, L. L (2018). An Analysis of Common Errors in ESL Descriptive Writing among Chinese Private School Students in Malaysia. International Journal of Education and Practice, 6(1), 28-42.

Nalliveettil, G. M., \& Mahasneh, A. (2017). Developing Competence in Basic Writing Skills: Perceptions of EFL Undergraduates. International Journal of Applied Linguistics \& English Literature, 6(7), 332-341.

Nicol, D. J. \& Macfarlane-Dick, D. (2006). Formative assessment and self-regulated learning: A model and seven principles of good feedback practice. Studies in Higher Education, 31(2), 199-218. 
Nik, Y. A., Sani, B. B., Kamaruzaman, M. N. B. W. C., Hasbollah, H. R. B., (2010). The writing performance of undergraduates in the University of Technology Mara, Terengganu, Malaysia. Journal of Languages and Culture, 1(1), 8-14.

Nunan, D. (2003). Practical English Language Teaching. McGraw-Hill.

Nyang'au, B. N. (2014). Challenges students face in learning essay writing skills in English language in secondary schools in Manga District, Nyamira County, Kenya. [Unpublished master's thesis]. Kenyatta University.

Pincas, A. (1982). Teaching English Writing. Macmillan Press.

Pratiwi, K.D. (2016) Students' difficulties in writing English (A study at the third semester students of English education program at University of Bengkulu Academic Year 2011-2012). Linguists: Journal of Linguistics and Language Teaching, 3(1): 1-17

Raimes, A. (1983). Techniques in Teaching Writing. New York: Oxford University Press.

Razak, N. A., Yassin, A. A., \& Moqbel, M. S. S. (2019). Investigating foreign language reading anxiety among yemeni international students in Malaysian Universities. Int. J. Eng. Linguist, 9.

Sarudin, I., \& Zubairi, A. M., \& Nordin, M. S., \& Omar, M. A. (2008). The English language proficiency of Malaysian public university students. Enhancing the quality of higher education through research: Shaping future policy. 40-65.

Silva, C. M., \& Yarborough, B. H. (1990). Help for Young Writers with Spelling Difficulties. Journal of Reading, 34(1), 48-53.

Solagha, O. Z. (2013). Writing Difficulties in the Swedish ESL-Classroom: How teachers of English deal with Students' writing Difficulties. Dept. of Language Education, Stockholms University.

Spawa. C. M., \& Hassan. F. (2013). "I doesn't know English": Beliefs and Practices in the Teaching of Speaking in ESL Classroom. Pertanika Journal of Social Sciences \& Humanities. 21 (2), $449-460$.

Tyner, E. (1987). College Writing Basics: A Progressive Approach. Belmont. Wands worth Publishing Company

Ujang, A, (2019, January 24). Malaysians struggling with English. The Sun Daily. Retrieved from https://www.thesundaily.my/opinion/malaysians-struggling-with-englishFC433412

Watcharapunyawong, S., \& Usaha, S. (2013). Thai EFL Students' Writing Errors in Different Text Types: The Interference of the First Language. English Language Teaching, 6(1), 67-78.

White, R. V. (2017). Teaching Writing English. Routledge.

Yahya, M. Y., \& Hashim, N. H. (2013). Difficulties and Ways to Improve English Writing Skills among Postgraduate ESL Students. In ICERI2013 Proceedings (pp.245-6252). IATED.

Zamel, V. (1985) Responding to student writing. TESOL Quarterly, 19(1), 79-101. 
Zheng, C., \& Park, Tae-Ja. (2013). An analysis of errors in English writing made by Chinese and Korean university students. Theory and Practice in Language Studies, 3(2), 1342-1360.

\begin{abstract}
About the Authors
Nurul Jannah Ahmad Ghulamuddin is a lecturer at Academy of Language Studies, Universiti Teknologi MARA Pahang, Malaysia. She holds a Bachelor Degree from Universiti Kebangsaan Malaysia a Master's Degree from International Islamic University of Malaysia, both majoring in TESL. Her research interests are teaching approaches and language learning strategies.
\end{abstract}

Siti Khadijah Mohd Mohari is a lecturer at the Academy of Language Studies, Universiti Teknologi MARA Pahang, Malaysia. She holds a Master's Degree in TESL from International Islamic University Malaysia. Her research interests include teaching approaches and language learning strategies.

Kamisah Ariffin is an Associate Professor at the Academy of Language Studies, Universiti Teknologi MARA Pahang, Malaysia. She has more than twenty-four years in teaching English courses at the tertiary level. Her research interests include cross-cultural communication, discourse analysis, and language use and preferences in the real world. Her research articles on these areas have also been published in both local and international indexed journals. 